Yeshiva University, Cardozo School of Law

LARC @ Cardozo Law

Articles

Faculty

2007

\title{
Hegel and the Becoming of Essence
}

David G. Carlson

Benjamin N. Cardozo School of Law, dcarlson@yu.edu

Follow this and additional works at: https://larc.cardozo.yu.edu/faculty-articles

Part of the Law Commons

\section{Recommended Citation}

David G. Carlson, Hegel and the Becoming of Essence, 3 Cosmos and History: The Journal of Natural and Social Philosophy 276 (2007).

Available at: https://larc.cardozo.yu.edu/faculty-articles/321

This Article is brought to you for free and open access by the Faculty at LARC @ Cardozo Law. It has been accepted for inclusion in Articles by an authorized administrator of LARC @ Cardozo Law. For more information, please contact larc@yu.edu. 


\title{
HEGEL AND THE BEGOMING OF ESSENGE
}

\author{
David Gray Carlson
}

\begin{abstract}
One of the more mysterious transitions in Hegel's mnoumental 'Science of Logic' is the transition from the last stages of Being into the shadowy negative realm of Essence. This paper assesses the logic of those steps, in which measure becomes fully present but unable to capture an absence Hegel will eventually name as Essence. The paper emphasizes that the correlativity that marks the realm of essence is already introduced in the final two chapters of Hegel's analysis of measure. It concludes by explaining why Hegel thought bad astronomy - the division of planetary orbit into centripetal and centrifucal force-illustrates the final sublation of quality and quantity. While quality and quantity both have 'beyonds', the realm of essence does not. Essence is revealed to be a totality that contains both itself and other (measure, or appearance) in a single correlation.
\end{abstract}

Keywords: Quality; Quantity; Essence; Measure; Hegel; Science of Logic

In the Science of Logic, Hegel derives essence from being. How precisely does this come about? This is an extraordinarily difficult moment in the interpretation of Hegel's logic. I have found only one essay on the subject. According to Professor Michael Baur:

Thought finds itself condemned to a perennial and arbitrary interplay of qualitative and quantitative alterations which lack any stable substance or truth of their own. In order to overcome this bad infinite regress, one cannot appeal to yet another kind of external determination, for the mere appeal to another determination as such can only perpetuate the infinite regress. The problem can be overcome only when one succeeds in articulating a kind of relation which is not a relation to Other at all, but rather a kind of self-relation. That is, once the sphere of Being has shown itself in its nullity, one must enter a sphere where all transition is no transition at all. ${ }^{.}$

This is a very nice summary, but it is performed at a very high level of generality. Where in this summary is any reference to the alien terms one finds in the chapter Hegel entitles 'The Becoming of Essence' (Das Werden des Wesens)? There, one encounters 'the infinite which is for itself' (fürsichseiende Unendliche) (SL 37I/WL I 384), ${ }^{2}$ absolute Indifferenz, and

I. Michael Baur, 'Sublating Kant and the Old Metaphysics: A Reading of the Transition from Being to Essence in Hegel's Logic', Owol Minerva, vol. 29, I998, pp. I39-64, p.139 \& p. I46.

2. G. W. F. Hegel, Science of Logic, trans. A.V. Miller, New Jersey, Humanities Press, I969, p. 37I (hence- 
inverse ratio of the factors (umgekehrtes Verhältnis ihrer Faktoren). What do these concepts mean and what role do they play? Furthermore, Hegel insists that an outmoded theory of planetary orbit - the alternation of centripetal and centrifugal force - somehow illustrates the sublation of quality and quantity and the becoming of essence. How does bad astronomy relate to the becoming of essence? Why, when Hegel knows centripetal and centrifugal force to be bad astronomy, does he invoke it?

Hegel's logic is a circular chain of necessary progressions. If the chain is broken anywhere, the Science of Logic is invalidated and may as well be chucked out the window. Every link of the chain must be inspected for weakness.

My intent in this paper is to examine the exact derivation of essence in the last part of Hegel's analysis of measure. The obscure link in the chain between measure and essence is, in my opinion, a valid one. If Hegel's logic fails, it doesn't fail here. It is possible to endorse the path toward essence through the infinite-for-itself and the inverse ratio of the factors. In the interest of demonstrating how these concepts work, I will first make a few points - quite familiar to veterans of Hegelian logic - about Hegel's method and how it proceeds. Second, I will bring the reader up to speed on the general dynamic of measure - the last subdivision in the realm of being and postern gate to the shadowy realm of essence. Third, I will slow down the discussion to examine the dialectic part of Hegel's theory of measure - real measure. It is here that the sublation of quality and quantity begins to manifest itself. I then examine the troika of absolute indifference, inverse ratio and, finally, essence itself. In these steps essence finally becomes. And in the course of this examination, I will try to show why Hegel invokes astronomical theory he knew very well to be decadent. This will allow us to pinpoint the moment when being yields its ghost to the realm of essence.

\section{HEGEL'S LOGICAL METHOD}

The prose in Hegel's Science of Logic is sibylline, ${ }^{3}$ and, in its interpretation, it is always useful to cleave to the fundamentals of Hegel's method. Often Hegel's sentences become clear only upon recalling the exact methodological point one is at. ${ }^{4}$

Hegel's method, as even the non-Hegelians know, proceeds in a triune way. First, the 'understanding' (Verstand) makes a one-sided proposition about the absolute, given previous derivations that have previously accrued. Its affirmative proposition, however, always leaves something out as it tries to account for all prior logical progress. The understanding therefore forgets.

Dialectical reason remembers. It reproaches the understanding for suppressing previforth SL); G.W.F. Hegel, Wissenschaft der Logik, Georg Lasson (ed.), Hamburg, Felix Meiner, 1975, p. 384 (henceforth WL).

3. See Theodor W. Adorno, Negative Dialectics, trans. E.B. Ashton, New York, Continuum, 200o, p.89. ('In the realm of great philosophy Hegel is no doubt the only one with whom at times one literally does not know and cannot conclusively determine what is being talked about, and with whom there is no guarantee that such a judgment is even possible').

4. See David Lamb, 'Teleology: Kant and Hegel', in Stephen Priest (ed.), Hegel's Critique of Kant, Oxford, Oxford University Press, 1987, pp. I73 \& I75. ('When reading Hegel one must be like a detective and search for clues, for Hegel does not leave the reader with any familiar objects') (footnote omitted). 
ously established steps in the interest of making a non-contradictory proposition of the logical progress. ${ }^{5}$ But dialectical reason ends up merely replicating the one-sided error of the understanding. By affirmatively proposing what the understanding has suppressed, dialectical reason itself suppresses what the understanding has validly discovered.

Speculative reason intervenes to show that the difference between the understanding and dialectical reason is what they have in common - negation of the other. In the speculative step, the two extremes of a syllogism reveal their fundamental negativity. Each side is not the other. But each side is the other. So each side negates itself in negating its other. The negated sides yield their being to a third. This negative surplus is a gain over the prior steps and justifies the adjective 'speculative', in its economic connotation of return on investment.

The three steps repeat themselves over and over until the Logic ends. But as the Logic progresses, the understanding becomes more sophisticated. It makes affirmative propositions at first, but it learns to make dialectical propositions in the realm of essence (SL 384/WL II 398). ${ }^{6}$ Indeed, in 'The Becoming of Essence', we shall see its newly won dialectical nature already on display. At the end of essence, the understanding abandons its 'negative' correlative point of view and learns to make notional or speculative propositions. In the subjective logic, the previously doubled propositions become triune. The story of the Science of Logic is how the understanding becomes speculative reason at the end, and how method merges with Being, the very material to which it is applied.

The triune structure repeats itself at the macro-logical level as well as the micrological level. The interpreter should expect that the first chapter of, say, measure is relatively immediate in its form. The second chapter is dialectical. It constitutes a splitting of the unified premise of the prior chapter. The third chapter resolves the contradiction of the second chapter and unifies the opposites. This pattern may replicate itself many times within chapters as well.

Measure itself is third to quality and quantity. It is therefore generally speculative compared to its predecessors. Yet measure itself splits in two, leading to the dialectical Doctrine of essence, where reflection is paired with sublated being (i.e., appearance). With this methodology in mind, we approach the becoming of essence through the logic of measure.

5. Dialectical reason equates with experience. That is, the understanding has made a proposal about the universe. By remembering the past dialectical reason inverts the proposition and reveals it to be the opposite of what it is. Dialectical reason is like experience in that 'theory' is shown to be inconsistent with the 'real' world known to exist beyond theory. Kenneth R. Westphal, Hegel's Epistemological Realism: A Study of the Aim and Method of Hegel's Phenomenology of Spirit, Dordrecht, Kluwer Academic Publishers, i989, p. I3o; G.W.F. Hegel, The Fena System, I804-5: Logic and Metaphysics, trans. John W. Burbidge and George di Giovanni, Kingston, McGill-Queen's University Press, I986, p. 53. ('experience, of course, is the conjoining of concept and appearance - that is, the setting in motion of indifferent substances, sensations, or whatever you will, whereby they become determinate, existing only in the antithesis').

6. 'The being of the determinations is no longer simply affirmative as in the entire sphere of being, but is now a sheer positedness, the determinations having the fixed character and significance of being related to their unity'; 'Sie sind statt Seiender wie in der ganzen Sphäre des Seins nunmehr schlechthin nur als Gesetzte, schlechthin mit der Bestimmung und Bedeutung, auf ihre Einheit'. 


\section{MEASURE IN GENERAL}

One can visualize Hegel's theory of measure as beginning with a solid 'immediate' sphere - immediate measure, the perfect unity of quality and quantity. A hole develops in this sphere which grows in size until it exactly coincides with the sphere. Measure's positivity is conquered by the negativity which organizes it. When there is a perfect coincidence between the external realm of measure (i.e., appearance) and the internal, negative organizing centre, we have reached the totalizing regime of essence.

Measure stands for the openness of the universe to determination by an external reflection. This is its quantitative side; 'pure quantity is indifference as open to all determinations provided that these are external to it and that quantity has no immanent connection with them' (SL 375/WL I 344 )..$^{7}$ But quantity has yielded to an internal integrity which resists determination by an outside intellect. This is the qualitative side of measure. Measure begins as an immediate unity - measure as specific quantity. So conceived, measure is a quantity of a quality, but, if the unity is immediate, the slightest change of quantum produces a different quality and so a different measure. At first measure is brittle.

Yet quality, at this stage, has proved to be an immunity from outside determination (SL 334/WL I 344). ${ }^{8}$ In other words, measure is not just a quantum, open to externally caused increase and decrease. It is also a quality immune from quantitative change. Quality survives a change in quantum. Every measure must have some 'give' to it - this is its quality. Measure is no longer so brittle. But neither is it immune from change. Quantity is changeability. There must be a range of immunity from change which is nevertheless open to change: 'the quantitative determinateness of anything is thus twofoldnamely, it is that to which the quality is tied and also that which can be varied without affecting the quality' (SL 334 /WL I 344). ${ }^{9}$ This is the stage of specifying measure.

In specifying measure, every measure has a rule - a range of quantitative variation within which quality does not change. For liquid $\mathrm{H}_{2} \mathrm{O}$, its rule would be between $\mathrm{O}^{\circ}$ and $\mathrm{IOO}^{\circ}$ centigrade. Rule is conceived as external to the matter it rules. Yet the specifying

7. 'die reine Quantität ist die Indifferenz als aller Bestimmung fähig, so aber, daß diese ihr äußerlich [sind] und sie aus sich keinen Zusammenhang mit denselben hat'.

8. 'As a quantum [measure] is an indifferent magnitude open to external determination and capable of increase and decrease. But as a measure it is also distinguished from itself as a quantum, as such an indifferent determination, and is a limitation of that indifferent fluctuation about a limit'; 'Als Quantum ist es gleichgültige Größe, äußerlicher Bestimmung offen und des Auf- und Abgehens am Mehr und Weniger fähig. Aber als Maß ist es zugleich von sich selbst als Quantum, als solcher gleichgültigen Bestimmung, verschieden und eine Beschränkung jenes gleichgültigen Hin-und Hergehens an einer Grenze’.

9. 'die Quantitätsbestimmtheit so an dem Dasein die gedoppelte ist, das eine Mal die, an welche die Qualität gebunden ist, das andere Mal aber die, an der unbeschadet jener hin- und hergegangen werden kann' Hegel summarizes this opening move succinctly in the Encyclopaedia Logic (Hegel, G. W. F., The Encyclopaedia Logic (I 830$)$, with the Zusätze: Part I of the Encyclopaedia of Philosophical Sciences with the Zusätze, trans. W. Wallace, Oxford, Clarendon Press, i975.):

'In so far as ... quality and quantity are only in immediate unity, to that extent their difference [is] equally immediate. Two cases are then possible. Either the specific quantum or measure is a bare quantum, and the definite being (there-and-then) is capable of an increase or a diminution, without Measure (which to that extent is a Rule) being thereby set completely aside. Or the alteration of the quantum is also an alteration of the quality' (EL § I08 R Wallace trans.) 
measure - the 'ruled matter' - has a quality, indifferent to outside determination, which manifests itself quantitatively.

To illustrate rule and its effect on the specifying measure, take the case of a baby with a fever. The thermometer represents the rule - anything between $37-39^{\circ}$ centigrade is a 'normal' temperature. Anything higher is a fever. The baby represents specifying measure - the thing we decide to measure. Both the thermometer and the baby have their unique quality and quantity and so two measures face each other. The imposition of rule on the ruled - the thermometer on the child - produces a third thing - the ratio between these two measures. Or, more colloquially, the baby heats up the thermometer but it is equally true that the thermometer cools down the baby. The reported temperature is not strictly speaking the baby's quantum or the thermometer's quantum but is a compromise between the quanta of the baby and the thermometer. All measures are therefore ratios of two other measures. And every measure has something which escapes externalization. Measure has now divided into two--the external and the internal. This is the dialectic realm of real measure.

The two measures are at first indifferent to each other. For example, the specific gravity of gold is I9.3. Specific gravity of gold is the ratio of (a) the density of gold to (b) the density of pure water at its maximum density at $4^{\circ} \mathrm{C}$, when both densities are obtained by weighing the substances in air. But gold is indifferent as to whether it is measured against water or measured against some other material. Because gold could have been measured against mercury or fine bordeaux, gold has a series of quanta. Properly, gold is all of these quanta. This implies that measure is a metonym. One never measures a thing directly; one rather gathers together a series of relations between specifying and specified measures. A thing is finally measured only when all its ratios of measure are present. When specifying measure is reduced to series of specified measures, we begin to see quality and quantity in the process of sublation. Measure is the unity of quality and quantity, yet in the centre of the series of measures is a master signifier that organizes everything, even while escaping direct measurement.

\section{THE SUBLATION OF QUALITY AND QUANTITY}

In real measure, every measured thing has serial being - the ability to be compared to any other serial being - and a resistance to being completely captured in this relation. This seriality Hegel names elective affinity (Wahlverwandtschaft). The specifying measure reveals itself to be a metonym. It cannot define itself. It can only reveal what it is by interacting with external specified measures, which are ultimately themselves metonyms.

The understanding proposes that affinity is continuity - metonymic things are continuous into their external measures. But dialectical reason protests that affinity is only half the story; something eludes the elective affinities - an empty centre that organizes them. This empty centre Hegel names substrate. The substrate is discontinuous with the series of measures and continuous at the same time. The substrate is what Hegel calls a 
true infinite. A true infinite stays what is while becoming something other. ${ }^{10}$ So when a thing is measured and measured again, it becomes something external and visible. Yet it stays what it is. The substrate is the series of measures. Yet it is also beyond the series of measures.

Measure is again split in two. Before there were two measures producing a third-a 'neutrality'. Now we have a different pairing. There is substrate, which is the beyond of measure. And there is the totality of measure. On the side of measure, continuity and discontinuity are joined in the 'nodal line' (Knotenlinie). 'Nodal line' invokes the image of a rope with knots in it. In between the knots, movement up and down the line represents ineffectual quantitative change. To leap over a node represents a qualitative change. The nodal line is illustrated by steam-liquid-ice. Between the nodes of ice and steam, quantitative change can occur without qualitative change in water-as-liquid. But if the temperature is pushed below $0^{\circ} \mathrm{C}$ or above $100^{\circ}$, radical qualitative change occurs - all at once. None of this has anything to do with the substrate $\left(\mathrm{H}_{2} \mathrm{o}\right)$, which stays what it is while manifesting itself in its measures.

Why must the side of measure be divided into a nodal line? This is the inheritance from immediate measure (specific quantity) and rule. Specific quantity meant that quality can be destroyed by quantitative change. Rule meant that every quality had (and is defined by) a range of indifference to quantitative change. These concepts imply that the substrate can be organized into a series of measures that validly report its state. On the side of measure, quantitative change leads to qualitative change - a change in the 'state' of the thing. Thus, a unit of some acid may take two units of this alkali to neutralize it or three of that alkali; the quality of the acid is its quantitative relation to the alkali. If any of the alkali is actually added to the acid, the acid undergoes a qualitative change; it is no longer acid but a neutral product. But the acid's substrate remains what it is regardless of how an external measurer, capable of inflicting change, drives the thing up and down its nodal line of possible qualitative changes. 'Thus there is posited the alternation of specific existences with one another and of these equally with relations remaining merely quantitative - and so on ad infinitum' (SL 334/WL I 385)."

This leads the understanding to propose that the substrate is the abstract measureless. Measure, as nodal line, stands over against it. Whatever happens on the nodal line side is of no concern to the substrate. Therefore, the nodal line has become purely quantitative vis-a-vis the substrate. That is to say, whatever happens on the nodal line does not change the substrate. The substrate is now immune from qualitative change. All measures of the substrate are strictly quantitative, which is to say indifferently and externally imposed.

What is important to see at this point is that measure is entailed in a duality between the nodal relation of quantity-quality, on the one side, and substrate, on the other. The

I0. See EL $\S 94$ R (Wallace trans.) The true infinite 'consists in being at home with itself in its other, or, if enunciated as a process, in coming to itself in its other'; PS 9 I6 I 'infinity means ...(a) that it is self-identical, but also ... different; or it is the selfsame which repels itself from itself or sunders itself into two.

II. 'so ist die Abwechslung von spezifischen Existenzen miteinander und derselben ebenso mit bloß quantitativ bleibenden Verhältnissen gesetzt, — - so fort ins Unendliche?. 
first side is measure as such - quantity and quality. The second side - the substrate - is something deeper than quantity-quality. ${ }^{12}$

The dialectical critique of this position consists in confronting the understanding with what it omitted. Since the nodal line is measure, and since measure is both quality and quantity, the nodal line is itself qualitative. That is to say, there is a qualitative difference between measure and substrate. Two indifferent qualities now face each other.

The speculative critique of the prior two positions emphasizes the negativity that they share. The nodal line is not qualitative, according to the understanding, but is rather continuous with the substrate. The nodal line is qualitative, according to dialectical reason, and therefore not quantitative and continuous. The speculative position is that the measureless is neither qualitative nor quantitative. This is the measureless in its concrete form. Hegel gives this speculative conclusion the name infinite-for-itself.

I said earlier that speculative reason consists in the sides of a syllogism exhibiting self-negativity. That is precisely what we have in the infinite-for-itself. The two sides of the infinite-for-itself are neither qualitative nor quantitative. Quality and quantity are for other. They represent the mere appearance of things. The Infinite is now 'for itself, not for other. Being-for-self was the speculative stage of quality in which being expelled all its content to become quantity. In effect, Measure is now exhibiting its being-for-self. It has expelled its content into the substrate. But the opposite is also true. The substrate has expelled its being into measure. There is a double movement in measure between the measured substrate and its specified measures. ${ }^{13}$ The nodal line both is and is not the substrate.

We now reach the final moves in measure - the moves that constitute 'The Becoming of Essence'. This is an exceptionally difficult chapter, and so our progress must be slow and careful.

\section{THE BECOMING OF ESSENCE}

\section{A. Absolute Indifference}

The understanding progressively learns as it proceeds. By now, its

I2. John Burbidge provides a different account. He seems to view the nodal line as giving rise to absolutely discontinuous qualities, conceived as distinct neutral compounds. John W. Burbidge, Real Process: How Logic and Chemistry Combine in Hegel's Philosophy of Nature, Toronto, University of Toronto Press, 1996, p. 47. This is true so far as it goes, but this leaves out the whole notion of substrate, which stands over from and is immune from (yet related to) the nodal line. Burbidge writes:

'Since there is no qualitative boundary the two [neutral com-pounds] share - at least to the extent that thought can anticipate it - they are simply external to each other. So we are far removed from even a minimal account that would enable us to understand the relation. From this perspective no explanation is possible. We cannot conceive what is involved; it is immeasurable' (p. 47 footnote omitted).

Thus, for Burbidge, what is immeasurable is qualitative change 'The transformation of one quality into another is defined as immeasurable' (p. 48). This seems to me off point. There is nothing inconceivable about the measureless. It represents the substrate which is immune from qualitative change through quantitative manipulation. It does not represent a property of qualitative transformations.

13. This doubleness of movement was discovered later by Hegel and appears only in the I83 r revision of the Science of Logic. Cinzia Ferrini, 'Framing Hypotheses: Numbers in Nature and the Logic of Measure in the Development of Hegel's System,' in Stephen Houlgate (ed.), Hegel and the Philosophy of Nature, New York, State University of New York, i998, pp. 283-310, p. 283. 
immediate proposition about the infinite-for-itself is decidedly dialectic in shape. Accordingly, it proposes that the substrate is not to be distinguished from measure. ${ }^{\mathrm{I4}}$

The absolute indifference (Indifferenz) of substrate and measure is the product of quality and quantity sublating themselves and yielding their being to the infinite-for-itself. ' $[\mathrm{T}]$ he indivisible self-subsistent measure' is 'wholly present in its differentiations' (SL 376/WL I 388). ${ }^{15}$ For this reason, absolute indifference is 'concrete, a mediation-withself through the negation of every determination of being' (SL 375/WL I 388). ${ }^{16}$ The understanding, then, has made a dialectical proposition about absolute indifference, an important event in the Bildungsroman of Absolute Idea.

\section{B. Inverse Ratio of the Factors}

The understanding has proposed that the substrate is a sameness that has difference within it - the difference between substrate and measure. This concreteness was named the substrate's absolute indifference from measure. Dialectical reason reverses the proposition. It proposes that the substrate is a difference which is the same. In other words, there is nothing in the substrate which is not entirely present in its measure. But, according to dialectical reason, substrate nevertheless retains its independence from measure. This is the step that Hegel calls the inverse ratio of the factors.

Inverse ratio is a term that hails back to the transition from quantity to measure. An example of quantitative inverse ratio is $x y={ }_{I} 6$. If $\mathrm{I} 6$ stays fixed, the increase of $x$ implies the decrease of $y$. The mathematician can determine $y$ by determining $x$. Yet it is not quite true that the variables $x$ and $y$ can be anything the external mathematician would have them be (consistent with multiplying out to I6). Rather, $x$ and $y$ have a moment of immunity from external manipulation; neither $x$ nor $y$ can be made equal to zero. Nor can the mathematician state the highest possible value of $x$ or $y$. This immunity was the quality of quantum re-emerging from its earlier sublation.

In the primitive inverse ratio, the product - $\mathrm{I} 6$ - stays fixed, through the will of the mathematician. This fixity represents quantum's dependence on outside external reflection to determine what it is. Now, at our more advanced stage, the fixed product (i6) has become a 'fixed measure' (SL 376/WL I 389). ${ }^{17}$ Recall that every measure is in fact a series of measures, organized by a measureless substrate. A substrate is not really measured until the totality of measures is present. And yet a substrate exists apart from this totality. Hegel's fixed measure is therefore the totality of the realm of being. This is substrate's limit. Substrate is the beyond of the totality of measures. It is different from and indifferent to measure and hence is now immune from the external reflection of a

\footnotetext{
I4. Rinaldi claims this category is 'nothing else than an analysis and critique - of unexcelled profundity, lucidity and rigor - of the ultimate foundations of Schellingian metaphysics ... ' Giacomo Rinaldi, A History and Interpretation of the Logic of Hegel, Lewiston, E. Mellen Press, I992, p. I78.

I5. 'das untrennbare Selbständige, das in seinen Unterschieden ganz vorhanden ist'.

I6. 'das Konkrete, das in ihm selbst durch die Negation aller Bestimmungen des Seins mit sich Vermittelte'.

I7. 'Das festes Maß'.
} 
measurer. Hegel describes the difference between the primitive and more advanced inverse ratios as follows: 'here the whole is a real substrate and each of the two sides is posited as having to be itself in principle [an sich] this whole' (SL $376 /$ WL I 388$).{ }^{18}$ In other words, substrate is its nodal line. So the sides are the whole and the whole are the sides. Yet the two sides are still different.

Why is measure now an inverse ratio? The point here is ultimately simple. Measure is now fixed. The entire series of measures is deemed present and accounted for in the nodal line. It may seem that the series of measures are infinite in number and therefore incapable of completion, but that is not so. Metonyms inherently refer to context - a completed idea. Completion is the key to the logic of the inverse ratio of factors. So, conceptually, every series is deemed to be present, even though, empirically, we could never gather together all the measures needed to exhaust a substrate's serial being. Each side - nodal line and substrate - purports to be the whole thing and its organizing other. Now recall that quantity stands for openness to external manipulation by a measurer. So if the inverse ratio of the factors is the whole thing, a measurer can only add an extra measure by embezzling from the whole a comparable quality and quantity and then presenting it as if it were something new. This is one sense in which the factors are in an inverse relation. Something new correlates with something abstracted from the old.

Another way of expressing the completion of fixed measure is to say that any new measure imposed by external reflection is superfluous. It is this surplus that proves the undoing of the realm of being. The fixed measure is simply beyond the influence of an external reflection. In this sense, the passage quoted earlier from Michael Baur's essay is correct. ${ }^{19}$ Any added measure is a meaningless surplus that cannot add to our knowledge of the thing.

The sides of the inverse ratio of the factors are quantitative and continuous, but they are still presented as different; it is possible to say that there is a qualitative difference between substrate and measure. Suppose one side puts itself forth as a quality. Hegel suggests that the other side must surrender its quality and be merely quantitative. The point is that two qualities meet each other as 'mere oppugnancies', in Shakespearean terms. ${ }^{20}$ One must strike the other down. Thus, of the two qualities, Hegel says that 'one of [them] is sublated by the other' (SL 376/WL I 389). ${ }^{21}$ But they are unified in a ratio nevertheless. And, Hegel further says, 'neither is separable from the other' (SL $376 / \mathrm{WL}$ I 389$).{ }^{22}$ So the assertion of one quality at the expense of the other is a useless endeavour. Furthermore, which side is quality and which quantity? The totality, which is both the fixed measure and the substrate that organizes it, is indifferent to whether one side is deemed quality and the other quantity. The totality is immune from any schema the external measurer can impose upon it.

I8. 'daß hier das Ganze ein reales Substrat, und jede der beiden Seiten gesetzt ist, selbst an sich dies Ganze sein zu sollen?

I9. See text accompanying footnote I.

20. William Shakespeare, Troilus and Cressida Act I Scene 3.

2I. 'als in deren durch die andere aufgehoben'.

22. 'von der andern untrennbar ist'. 


\section{Transition into Essence}

Absolute indifference and its obverse, the inverse ratio, are not yet essence. Hegel speaks of three deficiencies of these pre-essential stages. The first of these faults is that the determinate being of the substrate is 'groundlessly emerging in it' (SL 377/WL I 390). ${ }^{23}$ So far, substrate is a mere 'result and only in principle ... a mediation' (SL 376/ WL I 390). ${ }^{24}$ It still displays a moment of logical unconnectedness to its nodal line. No self-repulsion is on display, as it will be in essence. This is the qualitative fault of the preessential stages.

Second, external reflection can indifferently assign to the substrate or to the ratio the role of quality or quantity. Or it can reverse the assignment. This modulation back and forth shows that difference between the sides is imposed externally, whereas essence must be in and for itself. This is the quantitative fault of the pre-essence stages - that each side can be determined to be quality or quantity.

Third, since each of the sides can be assigned a qualitative or quantitative role, each side is inherently already both quality and quantity. 'Hence each side is in its own self the totality of the indifference' (SL 378/WL I 390). ${ }^{25}$ Each side therefore contains an opposition. This is the speculative fault of the pre-essential stages.

Because each side is the totality, each side can no longer go outside itself. To go into the other is only to go into itself. The pre-essence stages have now passed beyond quantity, which by definition always goes beyond itself. Going into the beyond (transition) has now gone into the beyond. Yet if there is no quantity, there can be no quality. Quality isolated is pure being. Pure being is pure nothing, and so quality too sublates itself. The one further step that must be taken 'is to grasp that the reflection of the differences into their unity is not merely the product of the external reflection of the subjective thinker, but that it is the very nature of the differences of this unity to sublate themselves' (SL $3^{8} 4$ /WL I 397). ${ }^{26}$

Hegel identifies the unity of absolute indifference and inverse ratio as 'absolute negativity' (SL 384/WL I 397). ${ }^{27}$ This negativity is a truly radical indifference. It is an indifference to being, which is therefore an indifference to itself, and even an indifference 'to its own indifference' (SL 384/WL I 397) ${ }^{28}$ Essence repulses itself from itself. It is an active principle, in the nature of pure quantity. Indeed, at the beginning of essence, Hegel will confirm that, '[i]n the whole of logic, essence occupies the same place as quantity does in the sphere of being; absolute indifference to limit' (SL 39I /WL II 5) ${ }^{29}$ Essence is therefore a return to quantity, but in an enriched form - a form which never leaves itself

23. 'grundlos an ihr hervortretend'.

24. 'Resultat und an sich die Vermittlung'.

25. 'So ist jede Seite an ihr die Totalität der Indifferenz'.

26. 'Was hier noch fehlt, besteht darin, daß diese Reflexion nicht die äußere Reflexion des denkenden, subjektiven Bewußtseins, sondern die eigene Bestimmung der Unterschiede jener Einheit sei, sich aufzuheben'.

27. 'absolute Negativität'.

28. 'gegen ihre eigene Gleichgültigkeit'.

29. 'Das Wesen ist im Ganzen das, was die Quantität in der Sphäre des Seins war; die absolute Gleichgültigkeit gegen die Grenze'. 
as it repels itself from itself. Quantity, in contrast, has the defect of a beyond into which it continues. Essence is a totality with no beyond.

The determination of absolute indifference is 'from every aspect a contradiction' (SL $384 /$ WL I 397). ${ }^{30}$ First, it is 'in itself the totality in which every determination of being is sublated and contained' (SL $384 / \mathrm{WL}$ I 397). ${ }^{31}$ Yet it implies the inverse ratio of the factors as an externality. It is 'the contradiction of itself and its determinedness' (SL 384/WL I 397)..$^{32}$ Finally, it is a totality within which its 'determinatenesses have sublated themselves in themselves' (SL 384/WL I 397). ${ }^{33}$ The result is essence, 'a simple and infinite, negative relation-to-self (SL 384/WL I 397). ${ }^{34}$

That essence is simple is the contribution of the understanding, when it proposed that the substrate and the nodal line were one and the same. That it is infinite is to say that substrate goes outside of itself but remains what it is (though, now that externality has been abolished, 'outside' must be understood as really inside). ${ }^{35}$ As simple and infinite, the substrate has become essence.

Being has now abolished itself. Being turns out to be 'only a moment of [essence's] repelling' (SL 385/WL I 398). ${ }^{6}{ }^{6}$ The self-identity toward, which being strived so assiduously 'is only as the resulting coming together with itself (SL 385/WL I 398). ${ }^{37}$ Being is now essence, 'a simple being-with-self (SL 385/WL I 398)..$^{3}$

\section{Centrifugal and Centripetal Force}

By the time we reach the inverse ratio of the factors, measure is totally present. Being present, it is a self-sufficient totality to which external reflection can add nothing. The whole empirical world of measure is now necessary (and yet not sufficient) to measure anything fully. Since a totality is present, externality is cancelled. Any external subdivision or 'analysis' of measure is destructive of the perfect unity it has become.

To illustrate this necessity, Hegel digresses to discuss the orbit of the planets around the sun. Orbit stands for the self-sufficient totality that measure has become. Earlier, building on the insight that measure entails external imposition upon a phenomenon that is partly free and independent of outside observation, Hegel sets forth a hierarchy

\footnotetext{
30. 'nach allen Seiten als der Widerspruch gezeigt'.

31. 'Sie ist an sich die Totalität, in der alle Bestimmungen des Seins aufgehoben und enthalten sind'.

32. 'der Widerspruch ihrer selbst und ihres Bestimmtseins'.

33. 'deren Bestimmtheiten sich an ihnen selbst . . . aufgehoben haben'.

34. 'die einfache und unendliche negative Beziehung auf sich'.

35. Hegel says in the Encyclopaedia Logic:

'In the sphere of Essence one category does not pass into another, but refers to another merely. In Being, the form of reference is purely due to our reflection on what takes place: but it is the special and proper characteristic of Essence. In the sphere of Being, when some[thing] becomes another, the some[thing] has vanished. Not so in Essence: here there is no real other, but only diversity, reference of the one to its other. The transition of Essence is therefore at the same time no transition: for in the passage of different into different, the different does not vanish: the different terms remain in their relation' (EL § i i R Wallace trans.)

36. 'nur ein Moment ihres Abstoßens ist'.

37. 'nur ist als das resultierende, unendliche Zusammengehen mit sich'.

38. 'einfaches Sein mit sich'.
} 
in the natural sciences in terms of immunity from the imperialism of a measurer. ${ }^{39}$ 'The complete, abstract indifference of developed measure ... can only be manifested in the sphere of mechanics' (SL 33I/WL I 34I) $4^{40}$ Therefore, planetary orbit is the proper analogy for fixed measure. The orbit of Mars around the sun is supremely indifferent to its measurement by the earthly godfathers of heaven's light. In comparison, measure is less likely to be taken as presenting the totality of, say, organic life and still less of politics or constitutional law-'the realm of spirit' (SL 332/WL I 342).4'

Planetary orbit is the ideal venue for fixed measure - the realm of the inverse ratio of the factors. According to a discredited theory of astronomy, orbit can be broken down into centripetal and centrifugal force. Hegel knows that this 'analysis' of orbit is self-contradictory. Nevertheless, the false attempt to reduce orbit into its constituent parts represents the immunity of the inverse ratio of the factors to a like analysis of a measurer. No analytical 'breakdown' is possible at the level of the inverse relation of the factors. So just as orbit is immune from analysis, so is the inverse ratio.

In the false theory of planetary orbit, centripetal force is what draws the planets toward the centre. Centrifugal force drives the planets away from the centre. Their equilibrium is the elliptical orbit of the planet. Since Newton, however, physicists have identified centrifugal force as inertia, which is the very negation of force. Centripetal force is gravity - the unified force at work in planetary orbit. In modern physical theory, orbit is the unity of a force and a resistance to force.

Hegel refers to Kepler's Second Law - that planets in an elliptical orbit sweep equal areas with every increment of time..$^{42}$ Because the orbit is elliptical, this fact implies that the orbiting planet accelerates as it approaches perihelion - the closest distance to the sun - and decelerates as it approaches aphelion - the farthest distance from the sun. Of this fact, Hegel writes, 'the quantitative side ... has been accurately ascertained by the untiring diligence of observation, and further, it has been reduced to its simple law and formula. Hence all that can properly be required of a theory has been accomplished' (SL 380/WL I 393). ${ }^{43}$ But for Hegel this is not enough. Theory assumes centripetal and centrifugal force are qualitative, opposed moments. Quantitatively, however, one increases and the other decreases, as the planets, in their evil mixture, pursue their orbits. At some point, the forces reverse in dominance, until the next tipping point is reached.

'[T] his way of representing the matter', Hegel writes, 'is contradicted by the essentially qualitative relation between their respective determinatenesses which makes their

39. On this hierarchy, see David Gray Carlson, A Commentary to Hegel's Science of Logic, New York, Palgrave, 2007, p. 200-I.

40. 'Die vollständige, abstrakte Gleichgültigkeit des entwickelten Maßes ... kann nur in der Sphäre des Mechanismus statthaben?

4I. 'im Reich des Geistes'.

42. See James W. Garrison, 'Metaphysics and Scientific Proof: Newton and Hegel', in Michael John Petry (ed.), Hegel and Newtonianism, Kluwer Academic Publishers, Dordrecht, Holland, I993, pp. 3-16, p. 8.

43. 'Das Quantitative ... ist durch den unermüdlichen Fleiß des Beobachtens genau bestimmt und dasselbe weiter auf sein einfaches Gesetz und Formel zurückgeführt, somit alles geleistet, was wahrhaft an die Theorie zu fordern ist'. 
separation from each other completely out of the question' (SL 380/WL I 393). ${ }^{44}$ Each of the forces only has meaning in relation to the other. Neither can exist on its own. 45 To say, then, that one of the forces preponderates over its fellow is to say that the preponderant force is out of relation with its partner to the extent of the surplus. But this is to say that the surplus does not exist:

It requires but little consideration to see that if, for example ..., the body's centripetal force increases as it approaches perihelion, while the centrifugal force is supposed to decrease proportionately, the [centrifugal force] would no longer be able to tear the body away from the former and to set it again at a distance from its central body; on the contrary, for once the former has gained the preponderance, the other is overpowered and the body is carried towards its central body with accelerated velocity (SL 380-I/WL I 394). ${ }^{46}$

Only an alien third force could save centripetal or centrifugal force from being overwhelmed. But this is tantamount to saying that the real force that guides the planets sans check cannot be explained.

The transformation from weakness to strength of one or the other forces implies that 'each side of the inverse relation is in its own self the whole inverse relation' (SL $38 \mathrm{I} / \mathrm{WL}$ I 394). ${ }^{47}$ The predominant force implies its opposite, servient force. The servient force has not vanished. 'All that recurs then on either side is the defect characteristic of this inverse relation' (SL 38 I /WL I 395) $4^{4^{8}}$ Either each force is (wrongly) attributed a selfidentical existence free and clear of the other, 'the pair being merely externally associated in a motion (as in the parallelogram of forces)' (SL 38I /WL I 395). ${ }^{49}$ Or neither side can achieve 'an indifferent, independent subsistence in the face of the other, a subsistence supposedly imparted to it by a more' (SL $382 /$ WL I 395)..$^{\circ}$

The idea of intensity cannot help. ' $[\mathrm{T}]$ his too has its determinateness in quantum and consequently can express only as much force (which is the measure of its existence) as is opposed to it by the opposite force' (SL 382/WL I 395)..$^{51}$ In other words, intensity

44. 'Dieser Vorstellung widerspricht aber das Verhältnis ihrer wesentlich qualitativen Bestimmtheiten gegeneinander. Durch diese sind sie schlechthin nicht auseinander-zubringen'..

45. This recalls Hegel's critique of calculus, where $\delta y$ or $\delta x$ were qualitative and meaningless outside the ratio $\delta y / \delta x$.

46. 'Es ist eine sehr einfache Betrachtung, daß, wenn z.B. wie vorgegeben wird, die Zentripetalkraft des Körpers, indem er sich dem Perihelium nähert, zunehmen, die Zentrifugalkraft hingegen um ebensoviel abnehmen soll, die letztere nicht mehr vermöchte, ihn der erstern zu entreißen und von seinem Zentralkörper wieder zu entfernen; im Gegenteil, da die erstere einmal das Übergewicht haben soll, so ist die andere überwältigt, und der Körper wird mit beschleunigter Geschwidigkeit seinem Zentralkörper zugeführt'.

47. 'daß jede der Seiten des umgekehrten Verhältnisses an ihr selbst dies ganze umgekehrten Verhältnis ist'.

48. 'Es rekurriert damit nur an jeder Seite das, was der Mangel an diesem umgekehrten Verhältnis ist'. 49. 'und mit dem bloß äußerlichen Zusammentreffen derselben zu einer Bewegung, wie im Parallelogramm der Kräfte'. The parallelogram of forces describes the phenomenon that, if two forces exist as vectors, their average vector forms a parallelogram with the original vectors, provided one of the original vectors is multiplied by the imaginary number, $-\sqrt{\mathrm{I}}$.

50. 'keine ein gleichgültiges, selbständiges Bestehen gegen die andere erhalten kann, was ihr durch ein Mehr zugeteilt werden sollte'.

5I. 'da es selbst in dem Quantum seiene Bestimmtheit hat und damit ebenso nur so viel Kraft äußern 
is just a way of smuggling in the idea of the quantitative surplus, which is precisely not allowed because the measures are in a zero sum relation at this point. In any case, the sudden shift from predominant to servient implies qualitative change.

Now what has the failed theory of centripetal and centrifugal force to do with the inverse ratio of the factors? Hegel has said that, if centripetal force were predominant, nothing can explain why this force would not sublate centrifugal force once and for all, causing the planet to fly into the sun. Or, when centrifugal force is predominant, nothing can explain why the planets do not to disorder wander. So orbit must be utterly immune from the isolation of either force as a constituent part of the orbit. The orbit will not permit itself to be deconstructed externally in this way. Orbit has 'being in and for self'. Similarly, the inverse ratio of the factors is immune from externality generally. It has a being-for-self that is also a being-in-itself.

With regard to the illegitimate forces, Hegel writes, 'Each of these hypothetical factors vanishes, whether it is supposed to be beyond or equal to the other' (SL 379/WL I 392) $)^{5}{ }^{2}$ Orbit is simply indifferent to these external impositions. Similarly, any isolation by external reflection, when faced with a perfect equilibrium, implies their sublation in general. Isolation is the assertion of pure being - an impossibility. Qualitative surplus cancels itself, and with it goes quantity. This self-abolition of quality and quantity, Hegel comments paradoxically, 'constitutes itself [as] the sole self-subsistent quality' (SL 379/ WL I 392). ${ }^{33}$ And, just as orbit is immune from the measurer's intervention, so is the inverse ratio of the factors likewise immune.

Is the argument valid? My conclusion is yes. At the point where the argument is hazarded, the substrate - what organizes measure - was metonymic. It was a negative unity of all the measure relations that the thing has with all the other things in the world. The thing, being fixed and complete, does not permit quantitative disequilibrium of the measures. The mere attempt of any such surplus to manifest itself is self-destructive. Any such manifestation puts the surplus - a qualitative proposition - in a lethal isolation from the thing. This self-identical thing is thus radically incommensurate with any other thing, including itself. Such an entity destroys itself by its very logic. What is left is the beyond of the realm of quality and quantity - essence. Quality and quantity have beyonds. But essence does not. It has swallowed quality and quantity whole and made externality an internality.

\section{GONGLUSION}

Every Hegelian could have said in advance that essence comes about because quality and quantity sublate themselves. But how precisely does this unfold in the chapter Hegel names 'The Becoming of Essence'? That is an exceptionally difficult matter, with its use of bad astronomy and invocations of inverse ratios of factors. I have tried, in this

kann, d.h. nur insoweit existiert, als es an der entgegengesetzten Kraft sich gegenüberstehen hat'.

52. 'Jeder dieser sein sollenden Faktoren verschwindet ebenso, indem er über den andern hinaus, als indem er ihm gleich sein soll'.

53. 'dieser also sich zum einzigen Selbständigen macht'. 
paper, to show how this involves setting a substrate over against a completed world of measure. The two sides pass over into each other, and each side becomes not only its other but the unity of itself and its other. This introduces opposition into the sides. Now each side is the totality. External determination can no longer have any bite. Externality itself is sublated, leaving a negative residue that is a totality in and for itself. This is the realm of essence, which bears the cancelled world of measure as merely ideal moments within the totality. Measure becomes the world of appearances, against which essence stands. The fact that essence has been constituted as a totality is vitally important for the sequence that follows measure. Essence is a totality; it does not let its other go forth but rather contains it. It is reflective in nature. In reflection, 'the negative is thus confined within an enclosed sphere in which, what the one is not, is something determinate' (SL 639/WL II 282).54 The insular nature of essence and its very correlativity requires the groundwork in totality which emerges in the chapter Hegel names 'The Becoming of Essence'.

David Gray Carlson Professor of Law

Benjamin N. Cardozo School of Law

54. 'das Negative ist somit in einer um Schlossenen Sphäre gehalten, worin das, was das eine nicht ist, ist Bestimmtes ist'. 